\title{
Presumed consent for organ donation: illusion of a choice
}

\author{
Reeta Dar* \\ Central Health Education Bureau, Directorate General of Health Services, MOHFW, Government of India, India
}

Received: 02 July 2016

Revised: 11 July 2016

Accepted: 08 September 2016

\author{
*Correspondence: \\ Reeta Dar, \\ E-mail: reetadarkhasu@yahoo.co.in
}

Copyright: (c) the author(s), publisher and licensee Medip Academy. This is an open-access article distributed under the terms of the Creative Commons Attribution Non-Commercial License, which permits unrestricted non-commercial use, distribution, and reproduction in any medium, provided the original work is properly cited.

\section{ABSTRACT}

India has been following informed consent (opt- in) system of organ donation but soft pressures to shift to presumed consent (opt- out) system are simultaneously palpable. This paper describes presumed consent briefly and explains why the need to shift to this system is felt. The paper challenges the morality of presumed consent system and describes its use as absolutely unethical in view of socio cultural diversity, educational disparity and profound class stratification of our country. The paper throws some light on our own system which, unlike other countries, is not ready for this change. It focuses on thought-provoking issues that are deterrents to achieving increase in organ donation even if presumed consent system is adopted in India. It reflects the outcome of this coercive legal option in some countries. In some countries there was no change in organ donation rates. A few countries witnessed negative repercussions of presumed consent system. Some of these countries had no option except to revert back to opt- in system. The paper tries to give a message to the public and professionals by comparing Spain to India that has high donation rates in the world not because of presumed consent but because of other contributory factors. Spain initiated organ donation and transplant activities much ahead of India and their healthcare services are rated the best in the world. Socio-cultural, religious and political milieu unlike India is conducive to organ donation in Spain. Adequate investments in public health, adequate budget for organ donation and transplantation, excellent infrastructure, availability of public health assistance to $99 \%$ population, adequate availability of ICU beds, extending end of life care to all, positive approach to organ donation by majority of people, thorough professionalism and public trust is what makes Spain the best country in organ donation. The same is lacking in India. The paper warns us of this coercive option by drawing a parallel to the coercions that took place when India acted coercively to control population through compulsory sterilization and led to the wrath of masses in 1976. India as on date needs to focus on other issues to increase organ donation rates like development of infrastructure, developing well-functioning national, regional and state level organizations, building in trust of people, identifying potential donors, managing donors, caring for donor families, training manpower, increasing awareness on organ donation and transplantation, reimbursing fees to organ retrieval hospitals, merging efforts of various stakeholders, developing transparent and workable organ sharing policies and regular auditing of brain stem deaths.

Keywords: Presumed consent system (opt-out), Informed consent system (opt- in), NOTTO, NOTP

\section{INTRODUCTION}

In India pressures to shift to opt out - option or presumed consent especially from those who have very limited knowledge regarding this legislation are palpable which needs to be evaluated in view of following explanations.

\section{WHAT IS PRESUMED CONSENT SYSTEM?}

It means presuming that every person has consented to donate organs as well as tissues for transplantation in case he has not registered his will against such donation during life. A person who does not want his 
organs/tissues to be retrieved from his body for transplantation after death (brain stem death/brain death/natural death) is bound to document his will against donation during life in driving license, opt- out register or in a legal document as per the legal framework of a country; otherwise he is considered a willing organ/tissue donor. This option shifts its base to unwilling people and places a binding on them to register their will against donation.

In absence of such registered unwillingness it is presumed that individual an has consented to donate organs and persuading family is not required to retrieve organs or tissues. Some of the countries who have adopted presumed consent legislation are Austria, Belgium, Columbia, France, Italy, Norway, Singapore, Sweden and Spain. ${ }^{1}$

\section{WHY DO WE WANT PRESUMED CONSENT SYSTEM IN INDIA?}

Supply of organ and tissues is less in comparison to demand for the same worldwide and India is no exception to it. All over the world including India, opt-in option demands willingness of not only the individuals but families too. Families in many cases refuse to donate organs which disheartens the transplant community. Presumed consent in place gives them an authority and ownership of organs and tissues. It also ensures respite from humanitarian and professional efforts of persuading, explaining, counselling, and motivating families to donate organs of brain stem dead donors. The intended motive behind such attempts is to save the lives of patients waiting for organ transplantation.

\section{IS PRESUMED CONSENT SYSTEM ETHICAL IN INDIA?}

Organ donation involves two things; one is acceptance of brain stem death by the donor family; second is donation of organs from that brain stem dead donor. If we legalize presumed consent system we shall be presuming that everyone has understood brain stem death and has simultaneously accepted this form of death. In addition we shall be presuming that they have no objection to donation of organs and tissue in case the potential donor had not registered unwillingness to donate. The family consent to donate organs from that brain stem dead donor may not be required. Not only are there many types of tissues and organs in body, there are many types of deaths as well. ${ }^{1}$ Is it ethical to presume everything in this so called presumed consent when we know that there are universal debates and dilemmas about brain stem death? Further there is lack of understanding by not only people but professionals too about this form of death. ${ }^{2,3}$ Organ donation is sacred and treated as "gifts of life", and gifts cannot be stolen or robbed ethically. Some believe this option amounts to legitimate robbery of biological assets and encroachment into biological boundaries of human beings simultaneously. Presumed consent is nothing more than an illusion of a choice.

People are not that literate to understand the nuances of brain stem death and organ donation. India is a country where class stratification, uneven distribution of resources and socio cultural diversity prevail extensively. Besides this, psychosocial milieu of India is varied owing to different family structures, religious faiths, cultural norms and values that are interconnected with dying, death, body, soul, life after death etc. All these aspects are ingrained in organ donation from brain stem dead donors as was described by a few people and professionals in India.

- People assume that the person has a life after death and shall have to consume food in other world after death. They do bury the eatables with the person so that the person gets enough in other world. If some of his organs are removed for transplantation how he will assimilate the food there? How can we deprive him of these assets and send him without his own persona?

- A medical doctor enquired about soul of her mother as her mother's heart was beating in someone's chest after her mother's organs were retrieved following brain stem death. She enquired, when did the soul leave my mother's body? My mother's heart is still beating.

- Daughter-in-law after consenting to donate organs of a brain stem dead donor was questioned by lamenting and crying mother-in-law at home asking her what she had done. What about "Moksha" of my child? Will my child get "Moksha" (Salvation)?

People usually are absolutely illiterate or relatively illiterate. Can people understand what brain stem death is or we don't want them to understand? If they don't understand, well and good, we are not accountable. The narratives of doctors are usually in medical language which are not understood by the literate; leave aside the illiterate which forms a major portion of our society. If we tell a person that his patient is brain stem dead, it becomes difficult for him to understand what that really means because he sees that his patient is still alive with a beating heart. There have been incidents when relatives of patients expressed deep anger to organ transplant coordinators in India when they were approached by them for considering organ donation of their brain stem dead relative. Also, in many health awareness programmes when I talked about brain stem death, well educated people started talking about stem cells and asked questions. It was after the third or fourth such programme did I realize why people speak about stem cells. The word stem in brain stem death had landed them into an area which was never intended to be talked about. Similarly when I talked about tissue donation, people misinterpreted it as tissue paper. 
In India $33 \%$ of the people are living below poverty line who cannot afford basic facilities let alone a right to second lease of life through organ transplant. The way we are eyeing on people's bodies through this legislation is not ethical. We do not legally exercise our right on the unutilized property of people. Can we presume that if a person has not made a will of his property for his family, it means he wanted to give his property to poor people in need? Well, this will serve a better cause for the nation. So many night care shelters could be provided through such a great gesture. Homeless people would neither die of cold in winters nor of heat waves in summers. It may satisfy the soul of the dead person too. We have too many explanations towards this great social cause. We have every right to assume that if the person had desired to give his property to his children he would have definitely made a will to do so. Since he has not made a will in favor of his children and has simultaneously not shown his reluctance to give to the poor, we should presume that he wanted to give his property to the deprived people of this nation. We can even quote the narratives of few people who wanted to donate their bodies after death not for social cause but for preventing their children from performing last rites at death. They felt that their children had failed to take care of them during their lives in old age when they needed them the most. ${ }^{4}$

Exercising this law would mean favouring transplant tourism as these transplant surgeries are not within the reach of the common people in India. Transplant tourism is flourishing in various countries and India is no exception to it.

\section{CAN WE ACHIEVE INCREASE IN ORGAN DONATION THROUGH PRESUMED CONSENT SYSTEM?}

It is often quoted that India needs 1,50,000 organs, 20,000 livers and 50,000 hearts every year. But the fact is that can never be achieved even if we put this coercive option in place and simultaneously pool all the global transplant resources in India as globally in 2013 there have been only 117,700 solid organ transplants, with 78,950 kidneys and 25,029 livers. ${ }^{5}$ It is always a few people that shall be benefitted of these surgeries. We need not to be too optimistic with this option and we also need to be happy with our place in this world. It is only 77 countries that have deceased donation programme in place, 104 countries are performing kidney transplantation and only 73 countries are performing liver transplant and India is also one such country. ${ }^{5}$

Professionals tend to think of competing with Spain that has the highest deceased organ donation rates and also has presumed consent in place. There is a need to understand the diversity in these two countries. Spain is a developed country while India is a developing country. Spain has a small population of $46,507,760$ people who are primarily Christians with 77 percent Catholics who usually support organ donation. ${ }^{6,7}$ India on the other hand has $210,854,977$ with $79.80 \%$ Hindus, has multiple cultures and most of these people believe in intact body, soul, rebirth etc. ${ }^{8}$ About $90 \%$ of the Spanish population has a favourable opinion about organ donation whereas opinions are varied in India among different religions too. 9,10

India also lags far behind in comparison to Spain. The transplant legislation was approved in 1994 in India, about 15 years later than Spain that adopted this legislation in 1979. ${ }^{911}$ In Spain, National Level Organization called Organization Nacional de Transplants (ONT) was established in 1989 whereas National Organ and Tissue Transplant Organization, (NOTTO) a national level organization in India has been

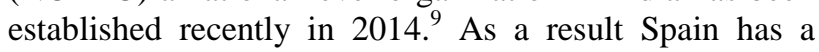
well-developed national level central office, 17 autonomous communities at regional level and 139 hospital coordination teams whereas the system in India is in the process of getting established with National, Regional and State level Organ and Tissue Transplant Organizations like NOTTO, ROTTO and SOTTO all over the country that will definitely take time. ${ }^{9,12}$ There is a need to look into the Investment on organ donation programme too which is 2999999 dollars per year in Spain whereas it has been 149.50 crores in $12^{\text {th }}$ Five Year Plan in India. ${ }^{9,13}$

The organ donation is also dependent on the availability of ICU beds and inadequacy of ICU beds in India is a major deterrent to diagnosis of brain stem deaths in India. ${ }^{14}$ Spain has 87.5 ICU beds per million in comparison to a meagre number of total 70000 ICU beds in India and Spain continues to take care of its people even if there are no chances of survival which cannot happen in India owing to less number of ICU beds. ${ }^{15,16}$

In Spain public health assistance is available to $99 \%$ population whereas in India $75 \%$ patients spend money out of their own pocket in tertiary care hospitals., ${ }^{9}$ Spanish healthcare services are well trusted and regularly rated among the world's best and has stringent Brain Death criteria for organ donation in place that has to be documented by a 30 minutes of silent EEG whereas India has an unregulated and unaccountable health system and follows brain stem death criteria (clinical diagnosis through apnoea test only and no EEG). ${ }^{9,18-20}$ The presumed consent system along with less stringent criteria of brain stem death diagnosis as is followed in India has greater chances of misuse in the private sector.

Spain also has a very efficient system in place, varying from potential donor detection, donor management, and reimbursement of fee to hospitals that provide organ donors and a continuous audit of brain stem death.,21 Developing this type of system in India is challenging and shall take time. ${ }^{12}$

A steady increase in cadaveric organ donation in Spain in one decade (1989- 98) from $14.3 \mathrm{pmp}$ to $35.1 \mathrm{pmp}$ is 
believed to be the result of availability of human resource that identify potential donors easily. India needs to focus upon this issue rather than on presumed consent. ${ }^{22} \mathrm{We}$ need not to be too optimistic about this system as India is a country where public trust on medical system is also of great concern. We need to understand the gravity of shortage of infrastructure and trained manpower as patients who have willing living organ donors are also succumbing to their diseases, waiting for transplant surgeries to be performed for more than a year. ${ }^{23}$

\section{DOES PRESUMED CONSENT SYSTEM ALWAYS LEAD TO INCREASE IN ORGAN DONATION?}

In developing countries the results of presumed consent are not that encouraging. ${ }^{24}$ In fact, no substantial increase in donation rates from deceased donors was perceived in countries like Chile by shifting from an opt-in to opt-out system in 2009 and the average deceased donation rates declined to 6.78 PMP (2009-2013) after implementing presumed consent which was 8.08 PMP (2004- 2008). ${ }^{25}$ Sweden continues to have low rates of organ donation although they have presumed consent legislation in place from 1996 onwards. In Brazil and France, this option led to negative repercussions and the country witnessed hostile response to organ donation. ${ }^{26}$

US alike India operates on opt-in system. Its organ donation rates are better than many other countries that have opt-out version in place. ${ }^{27}$ In fact it is not presumed consent but a combination of other factors like investment in health care, infrastructure and manpower, availability of donors, public attitude and awareness on organ donation and transplantation that play an important role in increasing organ donation. ${ }^{28}$

We need to draw lessons from the countries where this option did not work and need to be cautious with this coercive option as it may backlash the way our family planning programme did. The presumed consent in organ donation if adopted could meet the same fate as was met by national initiative on family planning during 1976-77 that eventually led to "forced sterilization" and brought unpardonable wrath of the common man. ${ }^{29}$

\section{CONCLUSION}

The presumed consent system is neither conducive nor ethical in the Indian context. India initiated national initiatives late. National Organ Transplant Programme was initiated in 2009 almost 16 years after passing on THOA-1994. About 16 years of lull by central government towards national initiatives left states and private organizations on their own to develop a mechanism of organ donation and transplantation. National Organ and Tissue Transplant Organization (NOTTO) is in the process of picking up the pieces together and trying to amalgamate efforts of all these stakeholders. The focus has to be on development of infrastructure like National Organ and Tissue Transplant
Organization (NOTTO), Regional Organ and Tissue Transplant Organization (ROTTO) and State Organ and Tissue Transplant Organization (SOTTO), effective functioning and coordination of these organizations, building in trust of people, identifying potential donors, managing donors, training manpower, increasing awareness on organ donation and transplantation, reimbursing fees to organ retrieval hospitals and auditing of brain stem death in India.

Funding: No funding sources

Conflict of interest: None declared

Ethical approval: Not required

\section{REFERENCES}

1. Dar R. Pressures and Promises: Policies and Legal Catalyzers for Deceased Organ Donation. IJSSIR. 2015;4(3):149-58.

2. Khashu DR, Dar SK. Peoples Perspectives: Insights into Organ Donation from Brain Stem Dead Donors. IOSR-JHSS. 2014;19(12):70-6.

3. Dar R, Adhish V. Debates and dilemmas of organ donation from Brain Stem Dead Bodies from the perspective of professionals. EIJMR. 2014;1(4).

4. Dar R, Grewal I, Kumar A, Adhish SV. Intra and inter-family influences on organ donation and transplantation. Health and Population-Perspectives and Issues. 2013;3(4):108-14.

5. GODT (2016). Global Observatory on Donation and Transplantation in collaboration with WHO. Retrieved on February 8, 2016 from http://www.transplantobservatory.org/Pages/Journal s.aspx

6. Cifras de Población a 1 de enero de 2014" (PDF) (in Spanish). June 30, 2014. Retrieved on March 6, 2015 fromhttp://www.ine.es/prensa/np870.pdf

7. Religion in Spain: Religious beliefs and organizations. Retrieved on February 8, 2016 from https://www.justlanded.com/english/Spain/Articles/ Culture/Religion-in-Spain

8. Our Census Our Future (2011) .Ministry of home affairs government of India. Retrieved on February 8,2016 from http://www.censusindia.gov.in/ 2011census/population_enumeration.html

9. Miranda B, Lucas MF, de Felipe C, Matesanz R. Organ donation in Spain. Nephrology dialysis transplant. 1999;14 (suppl3):15-21.

10. Oliver M, Woywodt A, Ahmed A, Saif I. (2011) Organ donation, transplantation and religion. Nephrol Dial Transplant. 2011;26:437-44.

11. THOA. Transplantation of Human Organs Act 1994. Central Act 42 of 1994. The Gazette of India, part II; section 3; sub section (i); July 8, 1994.

12. Dar R. National Organ and Tissue Donor Register: an initiative of National Organ and Tissue Transplant Organization (NOTTO). EIJMR. 2014;1(9).

13. NOTP Cell (2015).High lights of National Organ and Tissue Transplant program (NOTP) and 
operational guidelines for its implementation. DGHS: MOHFW: Government of India: New Delhi.

14. Yeolekar ME, Mehta S. ICU Care in India-Status and Challenges. J Assoc Physicians India. 2008;56:221-2.

15. John LRF. "Chapter 2: Organ donation in the UK: future progress and recent challenges Transplantation." Companion to Specialist Surgical Practice: 31. 2013. Retrieved on April 9,2016 from https://books.google.co.in/books?isbn=0702049689

16. Jayaram R, Ramakrishnan N. Cost of intensive care in India. Indian J Crit Care Med. 2008;12(2):55-61.

17. Hem C, Rinkoo AV. Access to Tertiary Care Treatment in India: A Ground Reality of Health Care Financing. Northeast Business \& Economics Association Proceedings. 2012:21-4.

18. Health care system in Spain expatica. Retrieved on July 30, 2015. http:// www. expatica. com/ es/ healthcare/ Getting- healthcare -in-Spain_ 101467.htmlL.

19. Jesani A, Nandraj S. The unregulated private health sector. Health for the Millions. 1994;2(1):25-8.

20. Dar R. Challenges to organ donation from brain stem dead persons in India. Nursing $\mathbf{J}$ India. 2014;(3):105-8.

21. Simini B. Tuscany doubles organ-donation rates by following Spanish example. Lancet. 2000; 355(9202):476.

22. Matesanz R, Miranda B. A decade of continuous improvement in cadaveric organ donation: the Spanish model. J Nephrol. 2002;15:22-8.

23. Varanasi. Despite PMO funding man dies waiting for a transplant. Financial Express. 2015. [Online]
Retrieved on July 30 ,2015 from http://www.financialexpress.com/article/miscellaneo us/varanasi-despite-pmo-funding-man-dies-waitingfor-kidney-transplant/94954/

24. Tumin M, Tafran K, Talib MA, Mutalib A, Satar N M, Said SM, et al. Demographic and Socioeconomic Factors Influencing Public Attitudes toward a Presumed Consent System for Organ Donation without and with a Priority Allocation Scheme. Medicine. 2015;94(42):e1713.

25. International Registry in Organ Donation and Transplantation (IRODaT). December 2014. [Online] Retrieved on Feb 27, 2015 from http://www.irodat.org/img/database/grafics/newslett er/IRODaT\%20Newsletter\%202013\%20.pdf

26. Bramhall S. (2011). Presumed consent for organ donation: a case against. Ann R Coll Surg Engl. 2011;93(4):270-2.

27. Zink S, Zeehandelaar R, Wertlieb S. Presumed versus Expressed Consent in the US and internationally. Virtual Mentor. 2005;7(9). doi: 10.1001/virtualmentor.2005.7.9.pfor2-0509.

28. Rithalia A, McDaid C, Suekarran S, Myers L, and Sowden A. Impact of presumed consent for organ donation on donation rates: a systematic review. BMJ. 2009;338:a3162,

29. Park K. Demography and Family Planning. Park's Text book of Preventive and Social Medicine Jabalpur. MP: BanarsidasBehnot. 2009; 444.

Cite this article as: Dar R. Presumed consent for organ donation: illusion of a choice. Int J Community Med Public Health 2016;3:2691-5. 